\title{
ТЕТРА- И ПЕНТАЦИКЛИЧЕСКИЕ УГЛЕВОДОРОДЫ В БИТУМОИДЕ ГОРЮЧЕГО СЛАНЦА КРАСАВА (НР БОЛГАРИЯ)
}

\author{
(Представил О., Эйзен)
}

Геохимическое значение тетра- и пентациклических углеводородов, впервые открытых в горючих сланцах около 20 лет тому назад ['], общепризнанно. При фоссилизации осадочного органического вещества (OB) биогенные стерановые и тритерпановые структуры претерпевают стереохимические и структурные превращения, и по конечному составу этих реликтовых углеводородов можно судить о степени катагенетической преобразованности ОВ и проводить корреляции с его биологическими предшественниками. При геохимической интерпретации состава стеранов и тритерпанов горючих сланцев очень ценна возможность сопоставления его с хорошо изученным составом стеранов и тритерпанов нефтей, которые обладают катагенетической зрелостью [ㄹ].

Сочетание капиллярной газовой хроматографии и масс-спектрометрии обеспечивает разделение сложных смесей изомеров стеранов и тритерпанов и идентификацию индивидуальных компонентов. Для получения быстрых и надежных результатов разработан компьютерный метод классификации стеранов и тритерпанов по их масс-спектрам [3], применяемый при исследовании нефтей $\left[{ }^{2}\right]$ и осадочных отложений ОВ, как древних [ ${ }^{4,5}$, так и современных [6].

В настоящей работе представлены результаты изучения пробы палеогенового горючего сланца Красава, начало битуминологическим исследованиям которого положено болгарскими учеными [ [7-9]. Содержание ОВ в ней $30,2 \%$, выход битумоидов А и С - соответственно 5,5 и $1,3 \%$ на ОВ. Битумоиды имеют следующий элементный состав:

\begin{tabular}{c|c|c|c|c|c|c}
\hline $\begin{array}{c}\text { Биту- } \\
\text { монд }\end{array}$ & $\mathrm{C}$ & $\mathrm{H}$ & $\mathrm{N}$ & $\mathrm{S}$ & $\mathrm{O}$ & $\mathrm{H} / \mathrm{C}_{\mathbf{a \tau}}$ \\
\hline $\mathrm{A}$ & 84,7 & 11,2 & 1,5 & 1,9 & 0,7 & 1,59 \\
$\mathrm{C}$ & 79,8 & 9,9 & 3,0 & 1,3 & 6,0 & 1,49
\end{tabular}

Содержание кислорода в битумоиде А очень низкое. В его составе преобладают нейтральные соединения $(90,3 \%)$, которые препаративной тонкослойной хроматографией (ТСX) [10] разделяли на ряд фракций и исследовали алкановую (выход 19,70\%), в которой сосредоточено основное количество стеранов и тритерпанов. Содержание нейтральных соединений в битумоиде С $(2,2 \%)$ оказалось недостаточным для разделения препаративной ТСХ. 


\section{Методика эксперимента}

Алканы битумоида А анализировали методом ГЖХ на хроматографе «Хром-5» и хромато-масс-спектрометрией в системе «Hewlett Packard» (хроматограф 5840A, масс-спектрометр 5985A, компьютер НР-1000). Колонки стеклянные капиллярные, 10 и 49 м $\times 0,25$ мм с OV-101 в качестве неподвижной жидкой фазы. Анализ проводили при программировании температуры. Газ-носитель - гелий. Энергия ионизирующих электронов 70 эВ.

\section{Результаты эксперимента}

н-Алканы битумоида А, идентифицированные методом поиска по иону c $m / z 71$, имеют бимодальное распределение с максимумами у $\mathrm{C}_{17}-\mathrm{C}_{19}$ и $\mathrm{C}_{27}-\mathrm{C}_{31}$. На хроматограмме (рис. 1) второй максимум замаскирован интенсивными пиками тетра- и пентациклических углеводородов. Преобладание «нечетных» гомологов над «четными» незначительное. Относительное содержание изопреноидных алканов $i$ - $\mathrm{C}_{14}-i$ - $\mathrm{C}_{20}$ высокое, как и содержание стеранов и тритерпанов. Пристан значительно преобладает над фитаном.

Стерановые углеводороды $\mathrm{C}_{27}-\mathrm{C}_{30}$ (табл. 1) идентифицированы поиском по ключевым ионам с $m / z 217$ (обычные стераны) и 231

Таблица 1

Стераны, идентифицированные в битумоиде А

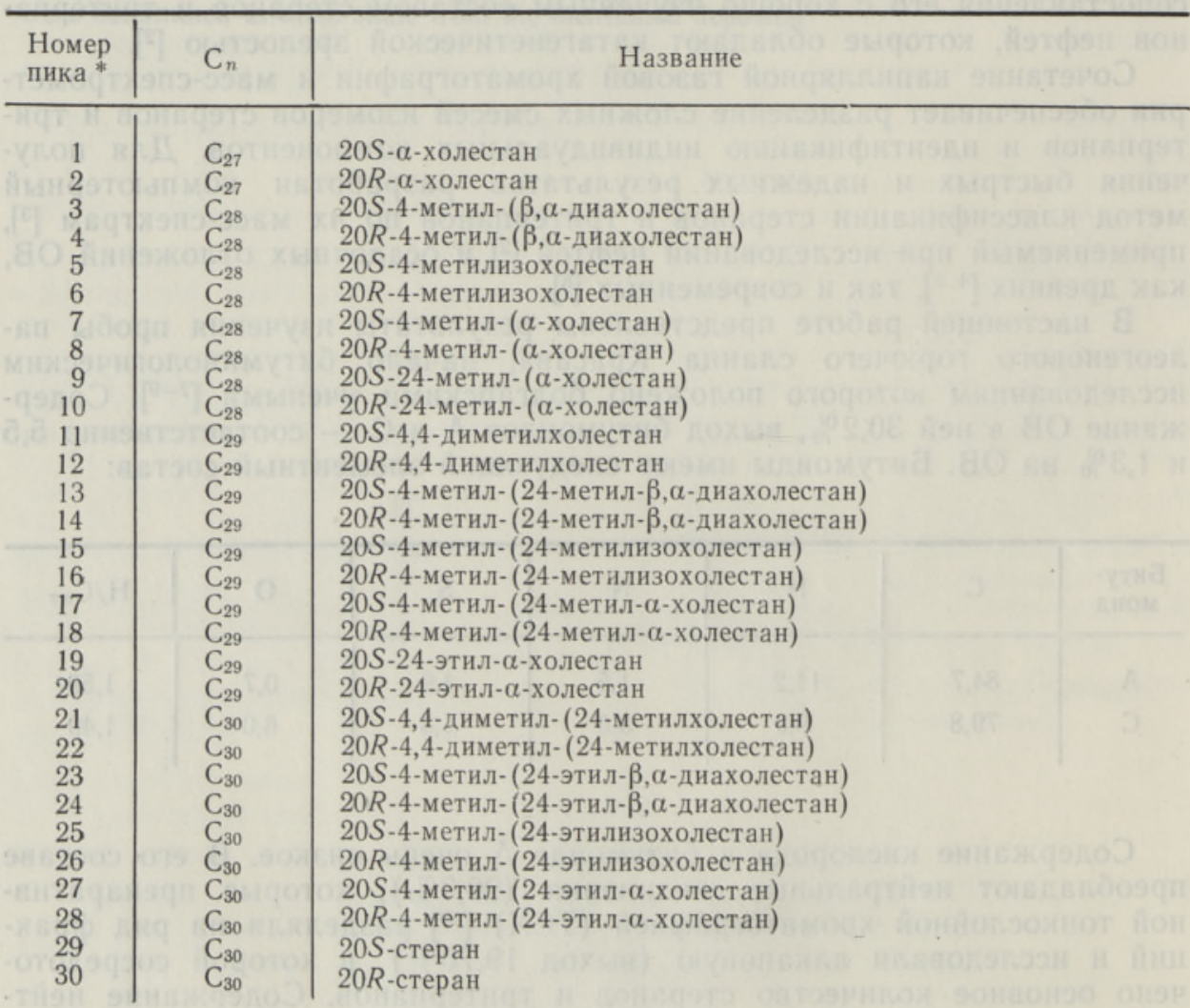

* См. рис. 3 . 
(4-метилстераны) (рис. 2, б, в) и поиском по молекулярным ионам с $m / z 372,386,400$ и 414 (рис. 3).

Первые представлены смесью 20S- и 20R-стереоизомеров $5 \alpha \mathrm{H}, 14 \alpha \mathrm{H}, 17 \alpha \mathrm{H}$ (табл. 1, рис. 3, пики 1,2,9,10,19,20), состав вторых сложнее и включает не только стереоизомеры $5 \alpha \mathrm{H}, 14 \alpha \mathrm{H}, 17 \alpha \mathrm{H}, 20 \mathrm{~S}$ и $20 R$ и $5 \alpha \mathrm{H}, 14 \beta \mathrm{H}, 17 \beta \mathrm{H}, 20 \mathrm{~S}$. и $20 R$, но и структурные изомеры $10 \alpha \mathrm{H}, 13 \beta \mathrm{H}, 17 \alpha \mathrm{H}, 20 S$ и $20 R$ 4-метилстеранов $\mathrm{C}_{28}-\mathrm{C}_{30}$ (табл. 1, рис. 3).

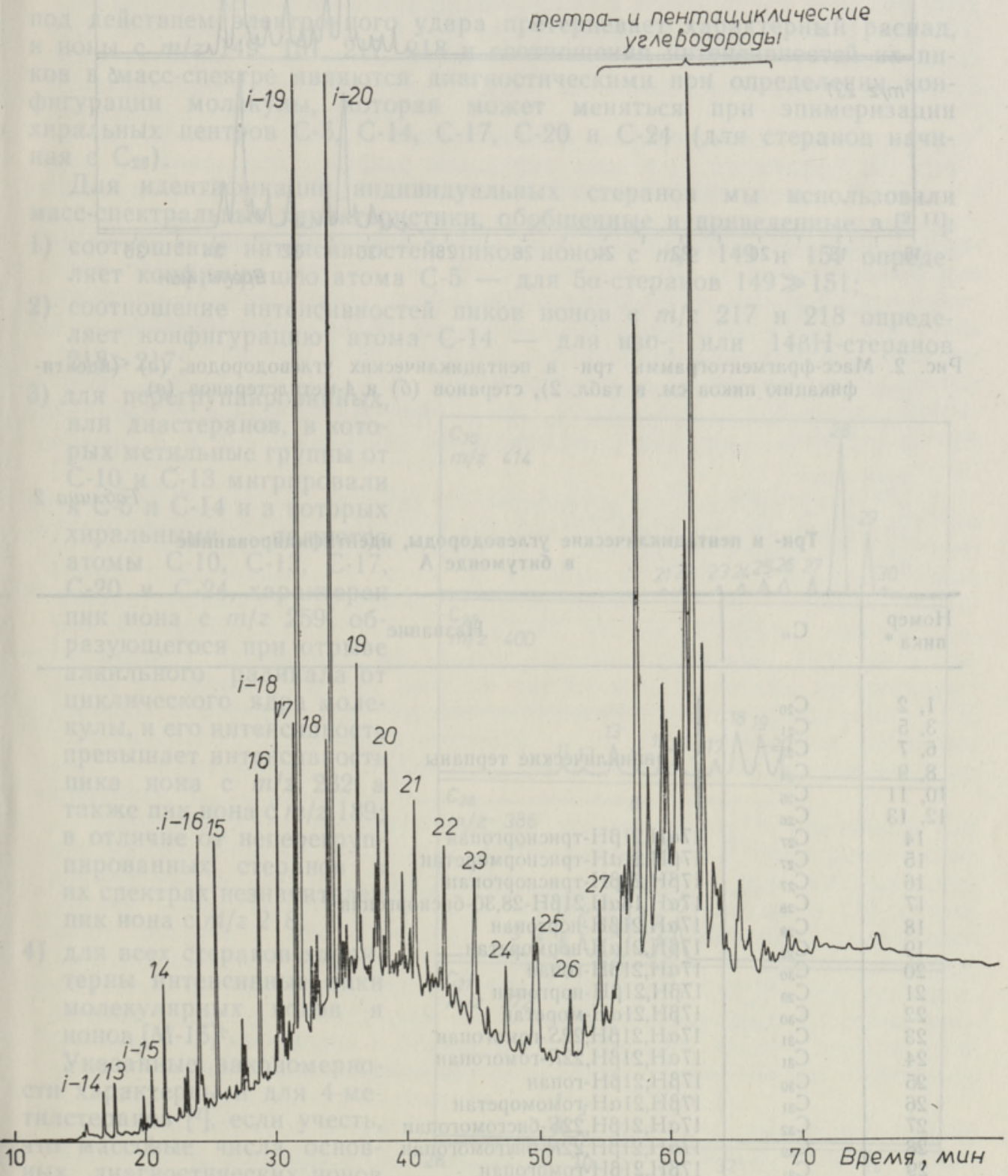

Рис. 1. Капиллярная хроматограмма алкановой фракции битумоида А. Цифры возле пиков обозначают число атомов углерода в соответствующих нормальных и изопренондных алканах. 


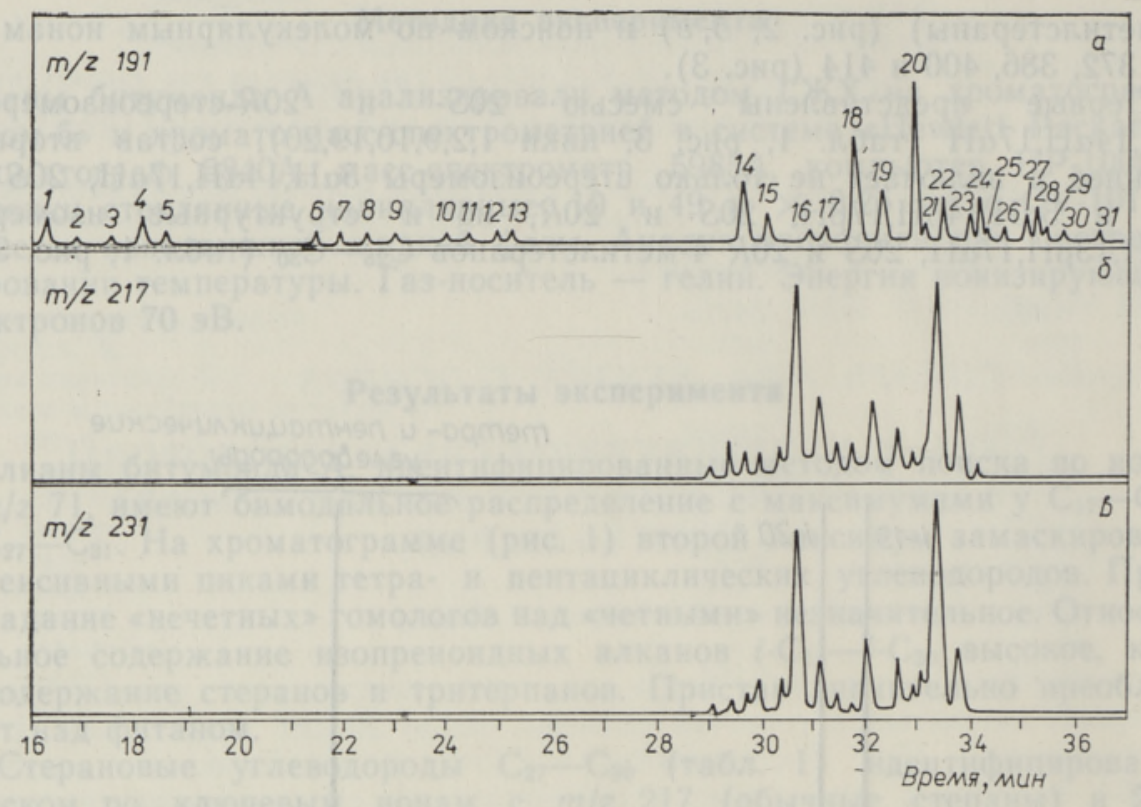

Рис. 2. Масс-фрагментограммы три- и пентациклических углеводородов (a) (идентификацию пиков см. в табл, 2), стеранов (б) и 4-метилстеранов (в).

Таблица 2

Три- и пентациклические углеводороды, идентифицированные в битумоиде А

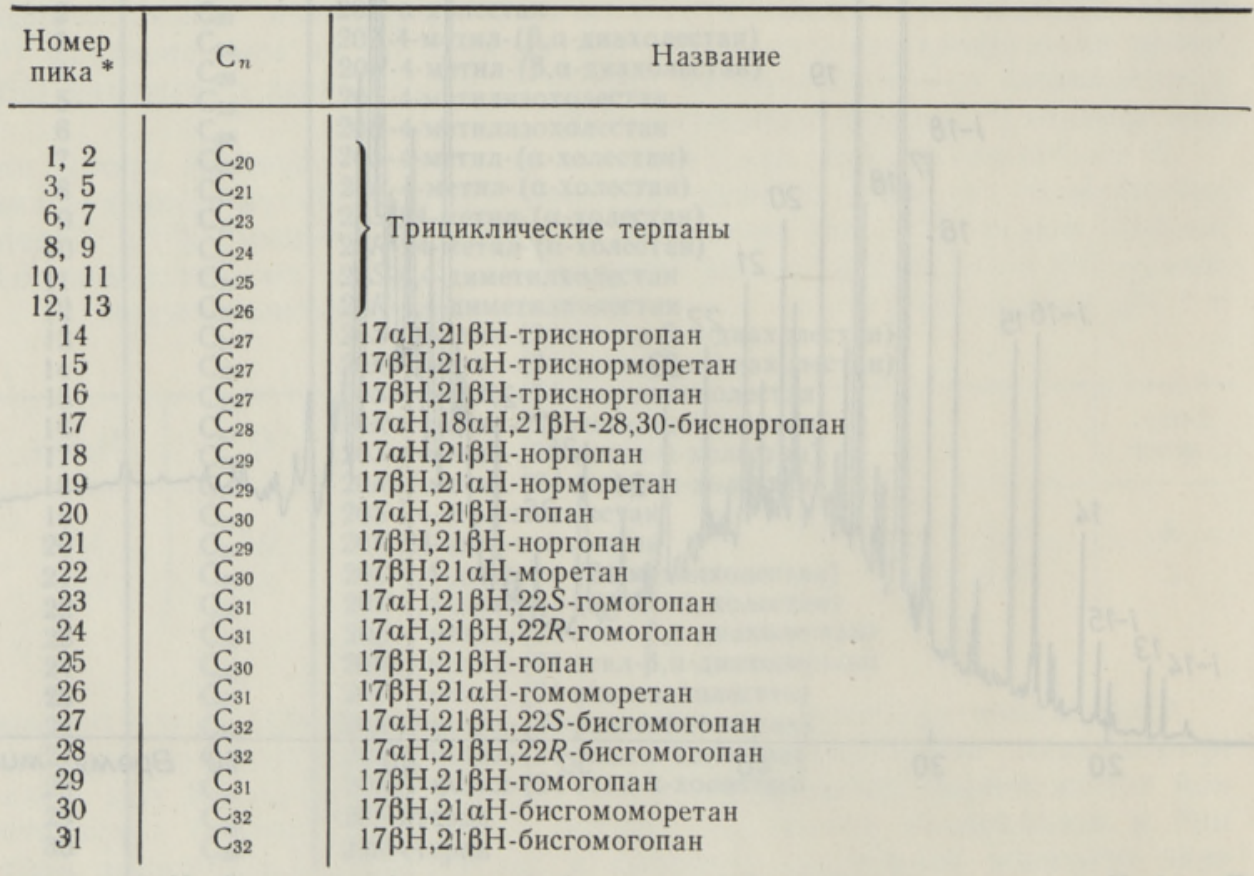

* См. рис. $2, a$ и рис. 4. 


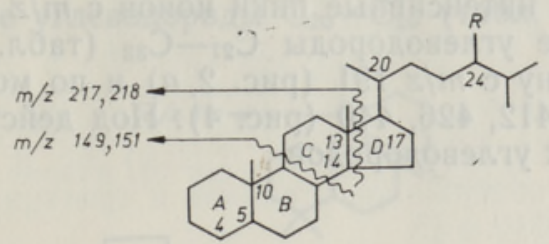

под действием электронного удара претерпевает характерный распад, и ионы с $\mathrm{m} / \mathrm{z} 149,151,217,218$ и соотношения интенсивностей их пиков в масс-спектре являются диагностическими при определении конфигурации молекулы, которая может меняться при эпимеризации хиральных центров С-5, C-14, C-17, С-20 и C-24 (для стеранов начиная с $\mathrm{C}_{28}$ ).

Для идентификации индивидуальных стеранов мы использовали масс-спектральные характеристики, обобщенные и приведенные в $\left[{ }^{2,11}\right]$ :

1) соотношение интенсивностей пиков ионов с $m / z 149$ и 151 определяет конфигурацию атома С-5 - для $5 \alpha$-стеранов $149 \gg 151$;

2) соотношение интенсивностей пиков ионов с $\mathrm{m} / z 217$ и 218 определяет конфигурацию атома С-14 - для изо-, или $14 \beta \mathrm{H}$-стеранов $218>217$

3) для перегруппированных, или диастеранов, в которых метильные группы от C-10 и С-13 мигрировали к С-5 и С-14 и в которых хиральными являются атомы C-10, С-13, C-17, C-20 и C-24, характерен пик иона с $m / z 259$, образующегося при отрыве алкильного радикала от циклического ядра молекулы, и его интенсивность превышает интенсивность пика иона с $m / z 232$, а также пик иона с $m / z 189$; в отличие от неперегруппированных стеранов в их спектрах незначителен пик иона с $m / z 218$;

4) для всех стеранов характерны интенсивные пики молекулярных ионов и ионов $[M-15]^{+}$.

Указанные закономерности характерны и для 4-метилстеранов [ $\left.{ }^{2}\right]$, если учесть, что массовые числа основных диагностических ионов увеличиваются на 14 единиц.

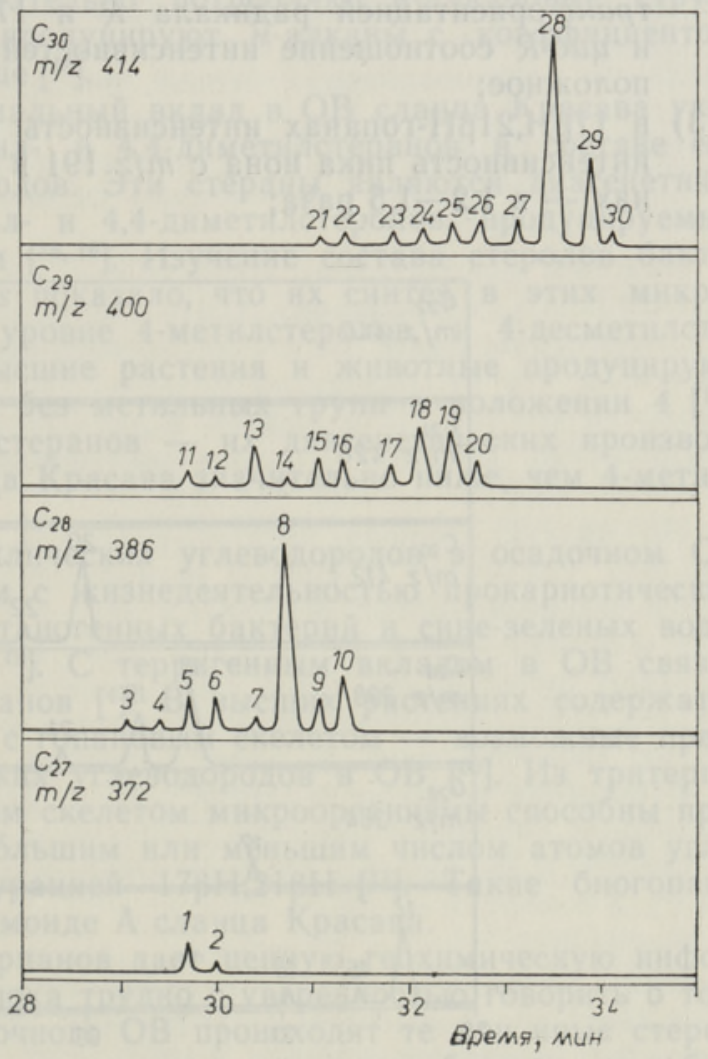

Рис. 3. Масс-фрагментограммы тетрациклических углеводородов. Идентификацию пиков см. в табл. 1 . 
Кроме обычных и 4-метилстеранов, в битумоиде А идентифицированы 4,4-диметилстераны $\mathrm{C}_{29}, \mathrm{C}_{30}$ (табл. 1, рис. 3), для масс-спектров которых характерны интенсивные пики ионов с $m / z 177,179$ и $245,246$.

Пентациклические углеводороды $\mathrm{C}_{27}-\mathrm{C}_{32}$ (табл. 2) идентифицированы поиском по иону с $m / z 191$ (рис. 2, $a$ ) и по молекулярным ионам с $\mathrm{m} / \mathrm{z} 370,384,398,412,426,440$ (рис. 4). Под действием электронного удара молекула этих углеводородов

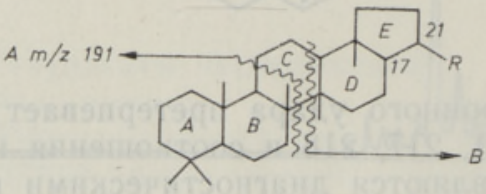

претерпевает характерную фрагментацию с образованием иона с $m / z 191$ (фрагмент $A$ ) и конкурирующий разрыв с образованием фрагмента $B$, масса которого зависит от массы молекулы. Для идентификации индивидуальных пентациклических углеводородов мы использовали диагностические соотношения интенсивностей пиков ионов $A$ и $B[2,11,12]$ :

1) в масс-спектрах $17 \alpha \mathrm{H}, 21 \beta \mathrm{H}$-гопанов с транс-сочленением циклов $A / B, B / C, C / D$ и ццис- $D / E$ пики ионов $A(\mathrm{~m} / z 191)$ превышают по интенсивности пики ионов $B$;

$2)$ для $17 \beta \mathrm{H}, 21 \alpha \mathrm{H}$-гопанов (моретанов) с транс-сочленением $D / E$ и транс-ориентацией радикала $R$ и $17 \beta \mathrm{H}, 21 \beta \mathrm{H}$-гопанов с транс-D/E и цис- $R$ соотношение интенсивностей пиков ионов $A$ и $B$ противоположное;

3) в $17 \beta \mathrm{H}, 21 \beta \mathrm{H}$-гопанах интенсивность пика фрагмента $B$ превышает интенсивность пика иона с $m / z 191$ в 2 раза, а в $17 \beta \mathrm{H}, 21 \alpha$ Н-моретанах - в 1,2-1,5 раза;

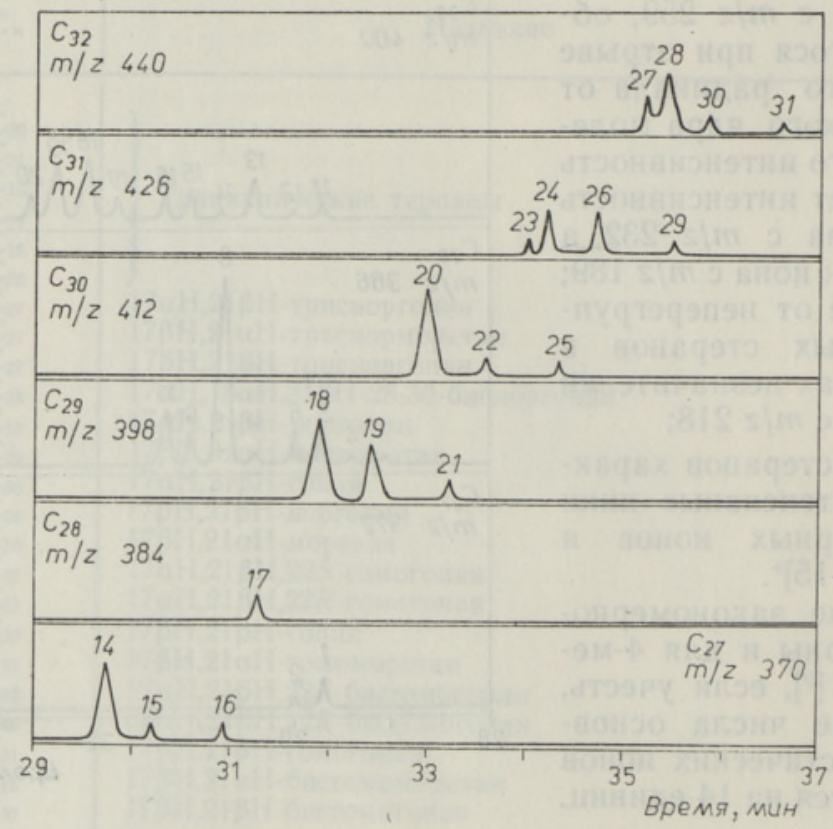

Рис. 4. Масс-фрагментограммы пентациклических углеводородов. Идентификацию пиков см. в табл. 2. 
4) в масс-спектрах пентациклических углеводородов интенсивны пиккй молекулярных ионов и ионов [M-15]+.

Трициклические углеводороды $\mathrm{C}_{20}-\mathrm{C}_{26}$ (табл. 2) со структурой

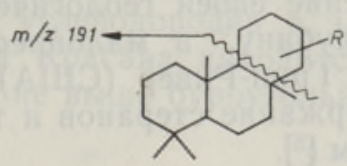

идентифицированы по пикам молекулярных ионов с $m / z 276,290,318$, $332,346,360$, по ионам [M-15]+ и по базовому пику иона с $m / z 191$. Масс-спектры этих углеводородов приведены в [13]. Трициклические углеводороды представлены смесью изомеров, положение радикала определить затруднительно.

\section{Обсуждение результатов и выводы}

Судя по составу н-алканов (рис. 1), в образовании ОВ сланца Красава принимали участие как фитопланктон, так и высшие наземные растения. Однако явное преобладание «нечетных» гомологов в $\boldsymbol{H}$-алканах, характерное для липидов этих биопродуцентов ОВ, почти утрачено, зато возросло относительное содержание изопреноидов, что типично для осадочного ОВ, претерпевшего в диагенезе переработку бактериями. Бактерии избирательно потребляют туры ОВ в осадке, а сами продуцируют н-алканы с коэффициентом нечетности, близким к единице [ $\left.{ }^{14}\right]$.

На значительный бактериальный вклад в ОВ сланца Красава указывает преобладание 4-метил- и 4,4-диметилстеранов в составе его тетрациклических углеводородов. Эти стераны являются диагенетическими производными 4-метил- и 4,4-диметилстеролов, продуцируемых метанотрофными бактериями $\left[{ }^{15,16}\right]$. Изучение состава стеролов бактерии Methylococcus capsulatus показало, что их синтез в этих микроорганизмах блокирован на уровне 4-метилстеролов, и 4-десметилстеролы не образуются $\left[{ }^{16}\right]$. Высшие растения и животные продуцируют стенолы и станолы $\mathrm{C}_{27}-\mathrm{C}_{29}$ без метильных групп в положении 4 [ $\left.{ }^{17}\right]$. Относительное содержание стеранов - их диагенетических производных - в битумоиде А сланца Красава значительно ниже, чем 4-метилстеранов.

Происхождение пентациклических углеводородов в осадочном ОВ связывают главным образом с жизнедеятельностью прокариотических организмов, в том числе метаногенных бактерий и сине-зеленых водорослей (цианобактерий) $\left[{ }^{18,19}\right]$. С терригенным вкладом в ОВ связывают наличие в нем моретанов [ [4]. В высших растениях содержатся тритерпеноидные структуры с гопановым скелетом - возможные предшественники пентациклических углеводородов в ОВ [20]. Из тритерпеноидов $\mathrm{C}_{29}$ и $\mathrm{C}_{30}$ с гопановым скелетом микроорганизмы способны продуцировать тритерпаны с бо́льшим или меньшим числом атомов углерода в молекуле с конфигурацией $17 \beta \mathrm{H}, 21 \beta \mathrm{H}\left[{ }^{11}\right]$. Такие биогопаны $\mathrm{C}_{27}-\mathrm{C}_{32}$ сохранились в битумоиде $\mathrm{A}$ сланца Красава.

Состав стеранов и тритерпанов дает ценную геохимическую информацию. Как отмечено в [2], пока трудно с уверенностью говорить о том, в диа- или катагенезе осадочного ОВ происходят те или иные стереохимические или структурные изменения в молекулах биогопанов и биостеранов. В конечном счете по составу стеранов и тритерпанов в фоссилизированном ОВ судят о степени его катагенетической преобразованности. 
Уже сам факт наличия тетра- и пентациклических углеводородов в сланце Красава можно рассматривать как признак того, что его ОВ не претерпело значительных термических превращений [21]. Эти углеводороды в заметных количествах содержатся в пермских сланцах Ирати (Бразилия), в течение своей геологической истории не погружавшихся на большую глубину, в малопреобразованных эоценовых сланцах Мессель (ФРГ) и Грин-Ривер (США) [21]. В тоарских сланцах Парижского бассейна содержание стеранов и тритерпанов уменьшается по разрезу от 700 до 2510 м [5].

Мерой катагенетической зрелости ОВ служит степень измененности конфигурации молекул биогенных стеранов и тритерпанов в процессе фоссилизации ОВ. Содержащиеся в битумоиде А сланца Красава $20 S$-изомеры $5 \alpha$-стеранов $\mathrm{C}_{27}-\mathrm{C}_{29}$ и 4 -метил- $5 \alpha$-стеранов $\mathrm{C}_{28}-\mathrm{C}_{30}-$ это первичные продукты превращения 20R-стеранов растительного, животного и бактериального происхождения, которые образуются при эпимеризации хирального центра С-20. На более глубокие превращения биостеранов указывает наличие изостеранов с конфигурацией $5 \alpha \mathrm{H}, 14 \beta \mathrm{H}, 17 \beta \mathrm{H}$. Они образуются при эпимеризации С-14, протекающей более медленно, чем эпимеризация С-20 [르. В результате транс-сочленение колец $C / D$ в биостеранах изменяется на термодинамически более стабильное циис-сочленение.

Наличие в сланце Красава $\beta, \alpha$-диастеранов с конфигурацией $10 \alpha \mathrm{H}, 13 \beta \mathrm{H}, 17 \alpha \mathrm{H}, 20 R$ и $20 S$ может быть связано с катализирующим действием алюмосиликатов (в минеральной части сланца их содержится $52,9 \%$ ), в результате которого из биостеренов образуются перегруппированные, или диастерены - промежуточные продукты в образовании диастеранов [22,23]. В превращении биостеранов в диастераны катализ на алюмосиликатах играет, очевидно, более важную роль, чем катагенный фактор. Так, в битуминозных мелах формации Гхареб (Израиль), содержащих катагенетически значительно преобразованное OB, а из минералов - в основном только биогенный кальцит, диастераны отсутствуют [4].

Важным показателем, вытекающим из состава стеранов, является коэффициент созревания ОВ: отношение $(20 R+20 S)$-изостераны/ $20 R, 5 \alpha$-стераны $\left[{ }^{2}\right]$. В ряду 4-метилстеранов сланца Красава он составляет 0,35 , что указывает на низкую степень катагенетической превращенности его ОВ. Для нефтей в ряду обычных стеранов - основных компонентов тетрациклических углеводородов - этот коэффициент равен $6,5-8,0\left[{ }^{2}\right]$.

На низкую степень катагенетической превращенности ОВ сланца Красава указывает и состав пентациклических углеводородов. Отношение гопанов $17 \beta \mathrm{H}, 21 \beta \mathrm{H} / 17 \alpha \mathrm{H}, 21 \beta \mathrm{H}$, т. е. био- и геогопанов, составляет 0,15 , как и для сланцев тех слоев Парижского бассейна, которые залегают значительно выше зоны генерации углеводородов [5]. В нефтях же $17 \beta \mathrm{H}, 21 \beta \mathrm{H}$-гопанов практически нет. По данным [5], они полностью изомеризуются до начала главной фазы нефтеобразования.

Отношение гопанов $22 S /(22 R+22 S)$, характеризующее степень эпимеризации хирального центра С-22 (начиная с $\mathrm{C}_{31}$ ), в сланце Красава составляет 0,36 , как и в слабопреобразованных слоях парижских сланцев [5], а в нефтях $-0,6\left[{ }^{2}\right]$.

Моретаны, как и биогопаны, также теряются с возрастанием степени катагенетической преобразованности ОВ [5]. Отношение $17 \beta \mathrm{H}, 21 \alpha \mathrm{H}$-моретаны/ $17 \alpha \mathrm{H}, 21 \beta \mathrm{H}$-гопаны $\left(\mathrm{C}_{29}+\mathrm{C}_{30}\right)$ в сланце Красава равно 0,27 , в нефтях - 0,08-0,10 [2], в битуминозных мелах формацин Гхареб, находящихся на предельной стадии перед генерацией углеводородов, - $0,12\left[{ }^{4}\right]$.

Таким образом, в результате хромато-масс-спектрометрического 
исследования состава тетра- и пентациклических углеводородов, экстрагированных из сланца Красава, получена геохимическая информация о генезисе и превращениях его ОВ в земной коре в процессе фоссилизации. По аналогии с углями, для которых было изучено изменение состава пентациклических углеводородов в зависимости от градации катагенеза [24], ОВ сланца Красава находится на стадии катагенетической преобразованности, не выше буроугольной.

\section{ЛИТЕРАТУРА}

1. Галлегос И. Дж. Ископаемые углеводороды биологического происхождения в горючих сланцах. - В кн.: Горючие сланщы. Л., 1980, 142-170.

2. Петров Ал. А. Углеводороды нефти. М., 1984.

3. Wardroper, A. M. K., Brooks, P. W., Humberston, M. J., Maxwell, J. R. Analysis of steranes and triterpanes in geolipid extracts by automatic classification of mass spectra. - Geochim. Cosmochim. Acta, 1977, 41, N 4, 499-510.

4. Rullkötter, J., Aizenshtat, Z., Spiro, B. Biological markers in bitumens and pyrolyzates of Upper Cretaceous bituminous chalks from Ghareb Formation (Israel). - Geochim. Cosmochim. Acta, 1984, 48, N 2, 151-157.

5. Mackenzie, A. S., Patience, R. L., Maxwell, J. R., Vandenbrouke, M., Durand, B. Molecular parameters of maturation in Toarcian shales, Paris Basin, France. 1. Changes in configurations of acyclic isoprenoid alkanes, steranes and triterpanes. - Geochim. Cosmochim. Acta, 1980, 44, N 11, 1709-1721.

6. Brassell, S., Gowar, A., Eglinton, G. Computerized gas chromatography-mass spectrometry in analysis of sediments from the Deep Sea Drilling Project. In: Adv. in Organic Geochemistry. Oxford-New York, et al., 1979, 421-426.

7. Вычев B., Керакова E., Ковачев $Г$., Цаков Кр. Геохимическая характеристика болгарских битумолитов. І. Некоторые предварительные результаты. - Нафт. и въгл. геол., $1975,1,14-25$.

8. Вычев В., Вычева А., Кабакчиева М., Петров Л. Геохимическая характеристика болгарских битумолитов. II. Сравнительный анализ битумолитов месторождений Красава, Мандра, Искра, Гурково, Боров дол. - Нафт. и въгл. геол., 1977, 7, 37-45.

9. Ангелова $Г$., Минкова В. Исследование растворимости органической массы горючих сланцев некоторых болгарских месторождений в органических растворителях. - В кн.: Горючие сланцы Болгарни. София, 1983, 43-48.

10. Klesment, I. Application of chromatographic methods in biogeochemical investigations. - J. Chromatogr, 1974, N 2, 705-713.

11. Шляхов А. Ф. Газовая хроматография в органической геохимин. М., 1984.

12. Seifert, W. K., Moldovan, J. M. The effect of thermal stress on source-rock quality as measured by hopane stereochemistry. - In: Adv. in Organic Geochemistry. Oxford-New York, et al., 1979, 229-237.

13. Gallegos, E. J. Identification of new steranes, terpanes and branched paraffins in Green River shale by combined capillary gas chromatography and mass spectrometry. - Anal. Chem., 1971, 43, N 10, 1151-1160.

14. Simoneit, B.R.T., Crisp, P. T., Rohrback, B. G., Didyk, B. M. Chilean paraffin dirt. II. Natural gas seepage at an active site and its geochemical consequences. In: Adv. in Organic Geochemistry. Oxford-New York, et al., 1979, 171-176.

15. Bird, C. W., Lynch, J. M., Pirt, F. J., Reid, W. W., Brooks, C. J. W., Middleditch, B. S. Steroids and squalane in Methylococcus capsulatus grown on methane. - Nature, 1971, 230, N 5294, 473-474.

16. Bouvier, P., Rohmer, M., Benveniste, P., Ourisson, G. 8(14)-Steroids in the bacterium Methylococcus capsulatus. - Biochem. J., 1976, 159, N 2, 267-271.

17. Gagosian, R. B., Smith, S. O., Lee, S., Farrington, J. W., Frew, N. W. Steroid transformations in recent marine sediments. - In: Adv. in Organic Geochemistry. Oxford-New York, et al., 1979, 407-419.

18. Chappe, B., Michaelis, W., Albrecht, P. Molecular fossils of Archaebacteria as selective degradation products of kerogen. - In: Adv. in Organic Geochemistry. Oxiord-New York, et al., 1979, 265-274.

19. Ensminger, A., van Dorsselaer, A., Spyckerelle, Ch., Albrecht, P., Ourisson, G. Pentacyclis triterpenes of the hopane type as ubiquitous geochemical markers: origin and significance. - In: Adv. in Organic Geochemistry. Paris, 1973, $245-260$.

20. Hills, G. R., Whitehead, E. V. Triterpanes in optically active petroleum distillates. - Nature, 1966, 209, N 5027, 977-979.

21. Хант Дж. Геохимия и геология нефти и газа. М., 1982. 
22. Sieskind, O., Joly, G., Albrecht, P. Simulation of the geochemical transformations of sterols: superacid effect of clay minerals. - Geochim. Cosmochim. Acta, $1979,43, \mathrm{~N} 10,1675-1679$.

23. Ensminger, A., Joly, G., Albrecht, P. Rearranged steranes in sediments and crude oils. - Tetrahedron, 1978, N 18, 1575-1578.

24. Гуляева Н. Д., Арефьев О. А., Петров Ал. А. Пентациклические углеводороды $\mathrm{C}_{27}-\mathrm{C}_{32}$ в органическом веществе углей различных градаций катагенеза. Хим. тв. топл., 1982, № 1, 30-35.

Институт химии

Академии наук Эстонской ССР
Поступила в редакцию 20/VI 1985

Jevgenia BONDAR, Maret KUUSIK, G. OSSIPOV

\section{TETRA- JA PENTATSOKLILISED SUSIVESINIKUD KRASAVA POLEVKIVI BITUMOIDIS (BULGAARIA RV)}

Bitumoidi alkaanide koostist uuriti kapillaarkromatograafia kromatomassispektromeetria meetoditega. Pōhjalikult uuriti tetra- ja pentatsükliliste süsivesinike koostist. Saadud andmed näitavad, et Krasava põlevkivi orgaanilise aine bioprodutsentideks olid fütoplankton ja kõrgemad taimed. Algne orgaaniline aine töötati diageneesiprotsessis ümber bakterite poolt. Krasava põlevkivi katageneesi aste on madal.

\section{Eugenia BONDAR, Maret KUUSIK, G. OSSIPOV}

\section{TETRA- AND PENTACYCLIC HYDROCARBONS IN THE EXTRACT OF KRASAVA OIL SHALE (BULGARIA)}

The composition of the alkane fraction in the extract of Bulgarian Krasava oil shale was studied by using capillary chromatography and computerized gas chromatographymass spectrometry. The composition of tetra- and pentacyclic hydrocarbons was in vestigated in greater detail. The data obtained show phytoplankton and higher plants to be the biological precursors of the organic matter in Krasava oil shale. During diagenesis the oil shale organic matter was strongly bacteria-altered. The maturity level of the oil shale is low. 